\title{
Potensi Anti Hiperkolesterolemia Ekstrak Tumbuhan Sarang Semut (Myrmecodia Pendans Merr. \& Perry)
}

\section{Potential of Anti Hypercholesterolemia from Extracts Myrmecodia Pendans Merr. \& Perry}

\author{
Hartono ${ }^{1}$, Iwan Setiawan ${ }^{2}$, Hari Saktiningsih ${ }^{3}$ \\ ${ }^{1,2}$ Akademi Farmasi Nasional Surakarta \\ ${ }^{3}$ Akademi Analis Kesehatan Nasional Surakarta
}

\section{Intisari}

Hiperkolesterolemia adalah salah satu gangguan kadar lemak dalam darah (dislipidemia) yang mana kadar kolesterol dalam darah lebih dari 240 $\mathrm{mg} / \mathrm{dl}$. Hiperkolesterolemia merupakan salah satu faktor risiko penyebab terjadinya penyakit jantung koroner yang merupakan penyebab utama dan pertama dari seluruh kematian. Kandungan flavonoid Tumbuhan Sarang Semut (Myrmecodia pendens Merr. \& Perry) memiliki potensi sebagai obat antihiperkolesterolemia, karena dapat menurunkan kolesterol total, Low Density Lipoprotein (LDL), dan dapat mencegah oksidasi LDL. Tujuan penelitian ini mempelajari potensi ekstrak tumbuhan sarang semut dalam menurunkan kadar kolesterol dan kadar Low Density Lipoprotein (LDL), serta kadar trigliserida serta peningkatan kadar HDL. Penelitian dilakukan dengan rancangan penelitian Pre and Post Randomized Controlled Group Design menggunakan binatang coba tikus putih (Rattus norvegicus) jantan, strain Wistar, dengan kriteria inklusi yaitu sehat dan mempunyai aktivitas normal, berumur kira-kira $12-16$ minggu dengan berat badan \pm 200 gram sebagai objek penelitian. Penelitian dilakukan dengan 6 kelompok tikus yaitu kelompok normal, kontrol negatif, kontrol positif dan 3 perlakukan dengan mempergunakan pemberian ekstrak sarang semut dengan dosis 400 $\mathrm{mg} / \mathrm{KgBB}, 600 \mathrm{mg} / \mathrm{KbBB}$ dan $800 \mathrm{mg} / \mathrm{KgBB}$. Analisa data kadar kolesterol total, trigliserid, HDL dan Low Density Lipoprotein (LDL) menggunakan one way ANOVA $a=0,05$ dengan uji lanjutan uji Tukey. Hasil penelitian menunjukkan bahwa secara kualitatif ekstrak tumbuhan sarang semut positif menunjukkan adanya senyawa flavonoid. Ekstrak tumbuhan sarang semut memiliki potensi sebagai antihiperkolesterolemia untuk menurunkan kadar kolesterol total dan menaikkan kadar kolesterol HDL secara bermakna pada dosis $800 \mathrm{mg} / \mathrm{KgBB}$. Uji one way ANOVA, ekstrak tumbuhan sarng semut memiliki probabilitas 0,004 lebih kecil daripada 0,05. Uji t test menunjukkan bahwa probabilitas 0,0046 < 0,025. Ekstrak tumbuhan sarang semut juga dapat menurunkan kadar trigliserid dan kolesterol LDL pada hewan uji namun tidak berbeda bermakna. Kesimpulan dari penelitian ini adalah ekstrak tumbuhan sarang semut memiliki potensi sebagai obat antihiperkolesterolemia menurunkan kadar kolesterol total dan meningkatkan kadar kolesterol HDL.

Kata Kunci : Ekstrak tumbuhan sarang semut, kolesterol total, LDL, HDL, Trigliserida 


\begin{abstract}
Hypercholesterolemia is one of the disturbances in blood lipid levels (dyslipidemia) in which blood cholesterol levels over $240 \mathrm{mg} / \mathrm{dl}$. Hypercholesterolemia is one of the risk factors associated with the occurrence of coronary heart disease is a major cause and first of all deaths. The content of flavonoids in Sarang Semut (Myrmecodia pendens Merr. \& Perry) has potential as anti-hypercholesterolemia drugs, because it can lower total cholesterol, Low Density Lipoprotein (LDL), and can prevent the oxidation of LDL. The purpose of this study was to determine the potential of sarang semut extracts in lowering cholesterol levels and levels of Low Density Lipoprotein (LDL), and triglyceride levels and increase HDL levels. The study was conducted by the research design Pre and Post Randomized Controlled Group Design uses animals try white rats (Rattus norvegicus) male, Wistar strain, with the inclusion criteria and have a healthy normal activity, aged about $12-16$ weeks with a weight of 200 grams \pm as the research object. The study was conducted with six groups of rats that baseline group, negative control, positive control and and 3 treated with the extract at a dose of 400 $\mathrm{mg} / \mathrm{Kg} \mathrm{BB}, 600 \mathrm{mg} / \mathrm{KgBB}$ and $800 \mathrm{mg} / \mathrm{Kg} \mathrm{BB}$. The data analysis of total cholesterol, triglycerides, HDL and Low Density Lipoprotein (LDL) using oneway ANOVA test $a=0.05$ by Tukey's test continuation. The results showed that the sarng semut extracts are qualitatively positive showed flavonoid compounds. Sarang semut extracts have potential as an anti hypercholesterolemia drugs to lower total cholesterol and increase HDL cholesterol levels significantly in a dose of $800 \mathrm{mg} / \mathrm{KgBB}$. One way ANOVA test, sarang semut extract has a probability of 0.004 is smaller than 0.05 . Test $t$ test showed that the probability of $0.0046<0.025$. Sarang semut extracts can also reduce levels of triglycerides and LDL cholesterol in test animals but was not significantly different. Conclusions of this study are the ant nest plant extracts have potential as drug antihiperkolesterolemia lower total cholesterol and increase HDL cholesterol levels.
\end{abstract}

Keywords: Myrmecodia Pendans extract, total cholesterol, LDL, HDL, Triglycerides

\section{Pendahuluan}

Penyakit jantung koroner (PJK) yaitu penyakit pada pembuluh darah arteri koroner jantung, di mana arteri/pembuluh darah tersebut menjadi lebih keras dan sempit (aterosklerosis) sehingga menyebabkan aliran darah ke otot jantung berkurang. Diperkirakan bahwa diseluruh dunia, PJK pada tahun 2020 menjadi pembunuh pertama tersering yakni sebesar 36\% dari seluruh kematian, angka ini dua kali lebih tinggi dari angka kematian akibat kanker. Di Indonesia dilaporkan PJK (yang dikelompokkan menjadi penyakit sistem sirkulasi) merupakan penyebab utama dan pertama dari seluruh kematian, yakni sebesar 26,4\%, angka ini empat kali lebih tinggi dari angka kematian yang disebabkan oleh kanker (6\%). Dengan kata lain, lebih kurang satu diantara empat orang yang meninggal di Indonesia adalah akibat PJK. Data WHO, 17 juta orang meninggal setiap tahun karena penyakit jantung dan pembuluh darah di seluruh dunia. Beberapa faktor resiko terpenting yang dapat menyebabkan terjadinya PJK adalah tekanan darah tinggi, merokok, diabetes mellitus, kegemukan, kurang olah raga, stress dan hiperkolesterolemia (Anonim, 2009).

Hiperkolesterolemia merupakan salah satu faktor risiko penyebab terjadinya penyakit jantung koroner. Terdapat sekitar 36 juta penduduk atau sekitar 18\% dari total penduduk Indonesia yang menderita kelainan lemak darah ini. 
Dari jumlah tersebut, $80 \%$ meninggal mendadak akibat serangan jantung, dan 50\%-nya tidak menampakkan gejala sebelumnya. Kadar kolesterol yang terlalu tinggi dapat memicu terjadinya proses aterosklerosis atau timbulnya plak ateroma yang dapat menyumbat pembuluh darah koroner pada jantung. Oleh karena itu, masalah hiperkolesterolemia menjadi penting untuk diatasi agar dapat mengantisipasi penyakit kardiovaskuler yang salah satunya adalah penyakit jantung koroner.

$$
\text { Tumbuhan }
$$

Sarang

Semut (Myrmecodia pendans Merr. \& Perry) merupakan tanaman obat yang berasal dari Papua berkhasiat untuk menyembuhkan berbagai macam penyakit dan secara tradisional telah digunakan untuk mengobati berbagai penyakit secara turun-temurun. Beberapa penelitian menunjukkan tanaman ini mengandung senyawa aktif penting seperti flavonoid, tannin, antioksidan tokoferol (vitamin E) dan beberapa mineral lainnya seperti kalsium, natrium, kalium, seng, besi, fosfor dan magnesium (Subroto, 2006). Flavonoid sebagai salah satu senyawa polifenol yang dapat menurunkan kadar kolesterol darah melalui peningkatan ekskresi asam empedu dan diyakini memiliki efek antioksidan untuk mencegah terjadinya oksidasi LDL (low density lipoproteins) dan reaksi inflamasi sehingga dapat mencegah perubahan dinding aorta. Beberapa penelitian menunjukkan oksidasi LDL oleh flavonoid 20 kali lebih kuat daripada vitamin E sebagai antioksidan alami. Kadar kolesterol plasma darah, terutama LDL digunakan sebagai indikator untuk mendiagnosis kemungkinan adanya gangguan jantung akibat aterosklerosis. Beberapa studi epidemologis menunjukkan adanya hubungan erat antara penurunan kadar kolesterol HDL dengan risiko PJK. Setiap peningkatan 1 $\mathrm{mg} / \mathrm{dL}$ kadar kolesterol HDL menurunkan risiko PJK 2\% pada laki-laki dan 3\% pada perempuan dan hal tersebut tidak dipengaruhi oleh kolesterol LDL (Anonim, 2006). \begin{tabular}{lrr}
\multicolumn{2}{c}{ Berdasarkan } & kandungan \\
flavonoid dalam Tumbuhan Sarang \\
Semut (Myrmecodia pendens Merr. \& Perry) \\
tersebut maka tanaman ini memiliki \\
potensi & sebagai & obat
\end{tabular} antihiperkolesterolemia. Namun demikian sampai saat ini penelitian potensi antihiperkolesterolemia ini belum dikembangkan. Penelitian ini bertujuan untuk membuktikan dan mengetahui potensi tumbuhan Sarang Semut (Myrmecodia pendans Merr. \& Perry) untuk mencegah kenaikkan kadar kolesterol total, kolesterol HDL, trigliserida, dan penurunan kolesterol LDL. Hasil penelitian ini diharapkan dapat memberikan informasi kepada penderita hiperlipidemia serta masyarakat tentang potensi tumbuhan Sarang Semut (Myrmecodia pendans Merr. \& Perry) sehingga dapat digunakan untuk memacu pendayagunaan obat tradisional dalam masyarakat sesuai dengan dasar-dasar ilmiah yang telah ada.

\section{Materi dan Metode}

Peralaan yang digunakan dalam penelitian ini adalah sonde lambung, tabung mikro kapiler, rak tabung reaksi, tabung sentrifuge, spuit, Vacuum rotary evaporator, pemanas water bath, spektrofotometer dan kandang hewan percobaan beserta kelengkapan pemberian makanan.

Subyek

penelitian mempergunakan Tikus putih (Rattus norvegicus) jantan, strain Wistar, dengan kriteria inklusi yaitu sehat dan mempunyai aktivitas normal, berumur kira-kira 12 -16 minggu dengan berat badan \pm 200 gram. Kriteria eksklusi pada penelitian ini adalah penurunan berat badan selama adaptasi $>$ $10 \%$, terlihat sakit selama masa adaptasi, pernah dijadikan hewan coba sebelumnya. Tikus putih diperoleh dari Laboratorium Farmakologi Akademi Farmasi Nasional Surakarta. Subjek penelitian dibagi menjadi 6 kelompok masing-masing terdiri dari 5 ekor tikus jantan yang dipilih secara random, yaitu kelompok pertama 
(I) merupakan kelompok normal (baseline) dimana tikus diadaptasi dengan diberikan pakan standar secara ad libitum selama 1 minggu; kelompok kedua (II) merupakan kelompok kontrol negatif yaitu kelompok tikus diberi pakan hiperkolesterolemia; kelompok III merupakan kelompok kontrol positif dengan pemberian obat penurun kolesterol Lipitor $40 \mathrm{mg}$, kelompok tikus diberi pakan hiperkolesterolemia serta obat lipitor $40 \mathrm{mg}$; kelompok IV merupakan kelompok perlakuan pemberian ekstrak tanaman sarang semut dosis I, kelompok tikus diberi pakan hiperkolesterolemia ditambah ekstrak tanaman sarang semut $400 \mathrm{mg} / \mathrm{KgBB}$; kelompok $\mathrm{V}$ merupakan kelompok perlakuan pemberian ekstrak tanaman sarang semut dosis II, kelompok tikus diberi pakan hiperkolesterolemia ditambah ekstrak tanaman sarang semut $600 \mathrm{mg} / \mathrm{KgBB}$; dan kelompok VI merupakan kelompok perlakuan pemberian ekstrak tanaman sarang semut dosis III, kelompok tikus diberi pakan hiperkolesterolemia ditambah ekstrak tanaman sarang semut $800 \mathrm{mg} / \mathrm{KgBB}$. Kelompok Perlakuan yaitu selain diberi pakan standar, diberikan tambahan ekstrak tumbuhan Sarang Semut (Myrmecodia pendans) peroral (sonde) dengan 3 dosis bertingkat selama 15 hari.

\section{Pembuatan ekstrak tumbuhan sarang semut}

Tumbuhan sarang semut dikeringkan dan diserbuk. Tumbuhan sarang semut untuk tikus kelompok IV sebanyak $400 \mathrm{mg} / \mathrm{kg}$ bb dikalikan 5 tikus, untuk kelompok V sebanyak $600 \mathrm{mg} / \mathrm{kg}$ bb dikalikan 5 tikus dan untuk kelompok VI sebanyak $800 \mathrm{mg} / \mathrm{kg}$ bb dikalikan 5 tikus. Masing-masing ditambahkan dengan aquades hingga volume $500 \mathrm{~mL}$ pada labu ukur kemudian dipanaskan diatas waterbath $\left(70^{\circ} \mathrm{C}\right)$ hingga volume tinggal $1 / 3$ bagian, disaring dan didinginkan. Ekstrak diberikan $2 \mathrm{ml} /$ tikus selama 14 hari.
Pembuatan

Hiperkolesterolemia

Pakan

Pakan hiperkolesterolemia dibuat dengan mencampurkan $100 \mathrm{~g}$ lemak babi $(10 \%)$ dan $50 \mathrm{~g}$ kuning telur $(5 \%)$ dalam 1000 g pakan standar. Sebelum dicampur dengan pakan standar, lemak kambing dipanaskan dahulu hingga mencair, dan kuning telur diambil dari telur yang telah direbus.

Pembuatan Tikus hiperkolesterolemia

Kelompok Tikus II-VI diberikan pakan hiperkolesterolemia sebanyak 20 $\mathrm{g} /$ hari/tikus selama 30 hari.

\section{Analisa kadar kolesterol, trigliserid dan lipoprotein (HDL dan LDL)}

Pengambilan darah untuk analisis kadar lipida dilakukan dengan cara, tikus dibius dengan menggunakan dietil eter. Dietil eter dimasukkan dalam cawan petri dan ditempatkan di bawah penyangga desikator plastik,dan ditutup rapat. Tikus dimasukkan ke dalam desikator dan ditutup rapat hingga pingsan, lalu tikus dibedah. Darah diambil melalui jantung dengan menggunakan disposable syringe berukuran $3 \mathrm{~mL}$ sebanyak $2 \mathrm{~mL}$. Darah dalam syringe disimpan dalam wadah es sampai siap dianalisis kadar lipida darah yang meliputi kadar kolesterol total, kolesterol LDL, kolesterol HDL, dan trigliserida (TG). Prosedur analisis kadar lipida darah menggunakan metode enzimatik kolorimetri. Pengukuran kadar kolesterol total, HDL dan LDL menggunakan metode CHOD-PAP dan untuk trigliserida dengan menggunakan metode GPO-PAP.

\section{Analisis Data}

Penelitian ini mengunakan Rancangan acak lengkap (RAL) dimana tikus dibagi menjadi enam perlakuan dengan lima kali ulangan. Analisis kadar kolesterol dan LDL mengunakan uji ANOVA dan dilanjutkan dengan uji 
Tukey nilai $\mathrm{p}$-value $(\mathrm{p}<0,05)$, mengunakan SPSS 20.0 For Windows.

\section{Hasil dan Pembahasan}

Rendemen dan Uji Kualitataif Flavonoid
Hasil ekstraksi tumbuhan sarang semut, kemudian dihitung rendemennya dengan membandingkan dengan bobot serbuk tumbuhan sarang semut awal. Hasil perhitungan menunjukkan bahwa rendemen hasil ekstraksi sebesar 20,30\% b/b. Uji kualitatif terhadap ekstrak tumbuhan sarang semut menunjukkan adanya flavonoid.

Tabel I. Uji kualitatif kandungan flavonoid ekstrak tumbuhan sarang semut

\begin{tabular}{c|l|lc}
\hline \multicolumn{1}{c|}{ Zat Uji } & \multicolumn{1}{|c}{ Pereaksi } & \multicolumn{2}{c}{ Keterangan } \\
\hline Ekstrak tumb sarang semut & $\begin{array}{l}\text { Serbuk } \mathrm{Zn} \mathrm{dan} \\
\mathrm{HCl}\end{array}$ & Terbentuk warna merah \\
\hline Ekstrak tumb sarang semut & $\mathrm{H}_{2} \mathrm{SO}_{4}$ pekat & $\begin{array}{l}\text { Terbentuk warna } \\
\text { kekuningan }\end{array}$ \\
\hline Ekstrak tumb sarang semut & $\mathrm{NaOH}$ & Terbentuk warna kekuningan \\
\hline Ekstrak tumb sarang semut & $\mathrm{FeCl}_{3}$ & Terbentuk warna kehitaman \\
\hline
\end{tabular}

\section{Kadar kolesterol total}

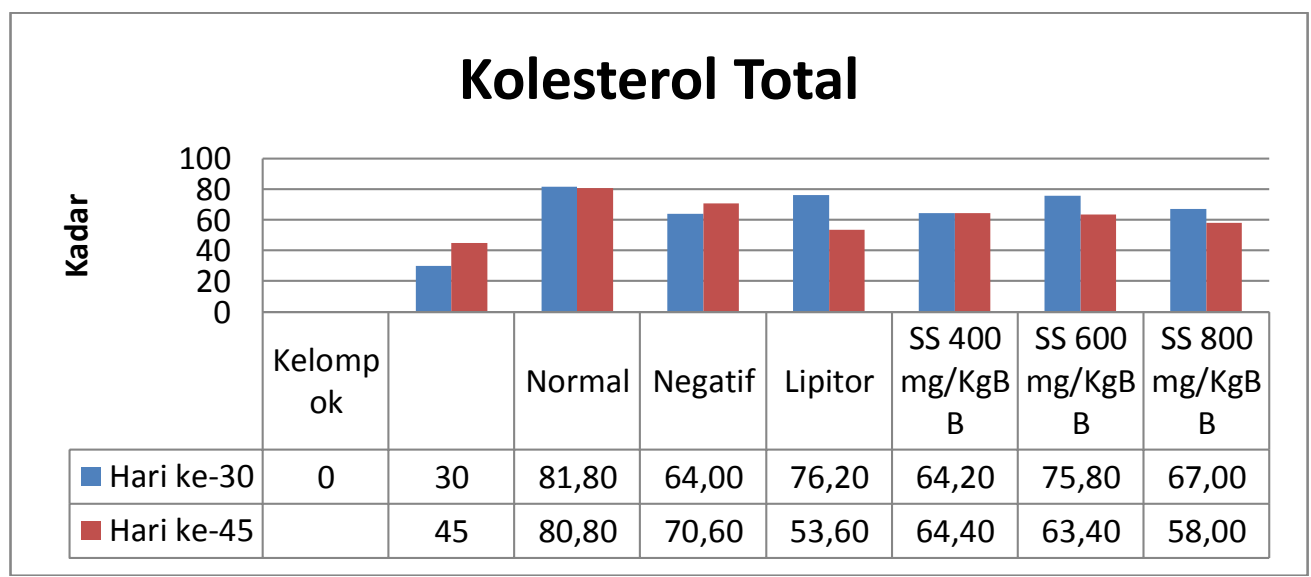

Gambar 1. Profil lipid hewan uji pada hari ke-30 dan hari ke-45

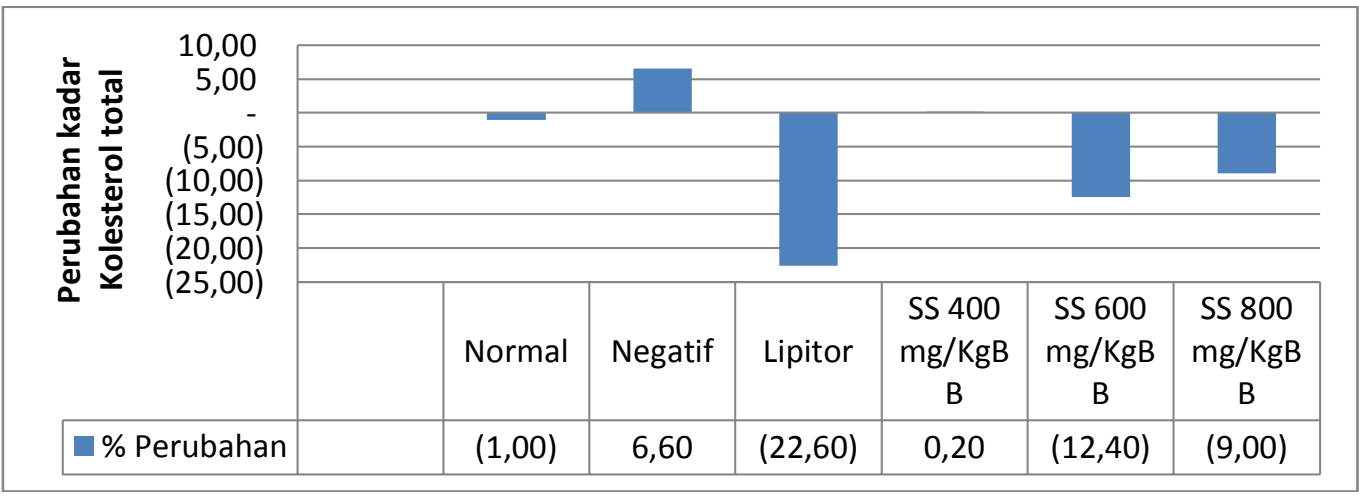

Gambar 2. Persen perubahan kadar kolesterol setelah pemberian sediaan uji 
Uji statistik secara ANOVA menunjukkan nilai $\mathrm{F}$ hitung adalah 4,757 dengan probabilitas 0,004. Karena probabilitas < 0,05 maka Ho diterima, ini berarti perlakuan yang diberikan terhadap hewan uji berbeda secara bermakna, khususnya pada Kontrol positif (lipitor) dan ekstrak tumbuhan sarang semut pada dosis $800 \mathrm{mg} / \mathrm{KgBB}$ terhadap perlakuan lainnya. Pada $t$ Test terhadap kadar kolesterol total menunjukkan probabilitas $\alpha<0,025$ pada hewan uji Kontrol Positif dan perlakuan pemberian sarang semut pada dosis $800 \mathrm{mg} / \mathrm{KgBB}$. Dengan demikian pemberin ekstrak tumbuhan sarang semut pada dosis $800 \mathrm{mg} / \mathrm{KgBB}$ dapat menurunkan kolesterol total pada hewan uji yang setara pada pemberian Kontrol positif (lipitor).

\section{Trigliserid}

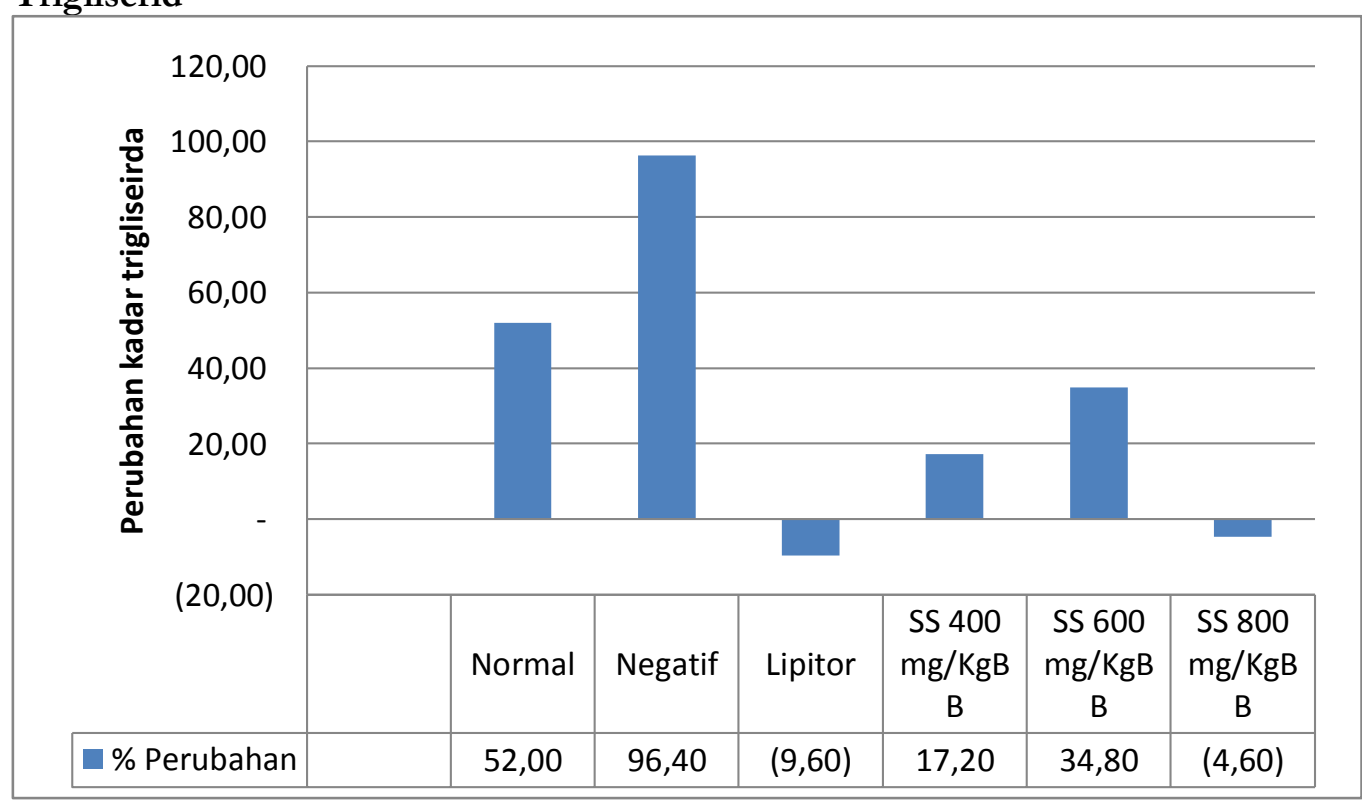

Gambar 3. Persen perubahan kadar trigliserida setelah pemberian sediaan uji

Berdasarkan gambar 3, pemberian ekstrak tumbuhan sarang semut dapat menurunkan kadar trigliserida pada semua dosis pemberian, namun demikian yang memberikan efek penurunan kadar trigliserida adalah pada pemberian ekstrak tumbuhan sarang semut pada dosis $800 \mathrm{mg} / \mathrm{KgBB}$ dan pada pemberian lipitor. Namun demikian uji statistik ANOVA menunjukkan nilai $\mathrm{F}$ hitung adalah 2,579 dengan probabilitas 0,053. Karena probabilitas $>0,05$ maka Ho diterima, berarti keenam perlakuan tidak berbeda bermakna. Uji $t$ Test menunjukkan nilai probilitas $\alpha>0,025$ berarti keenam perlakuan tidak berbeda bermakna. 
Kadar LDL/HDL

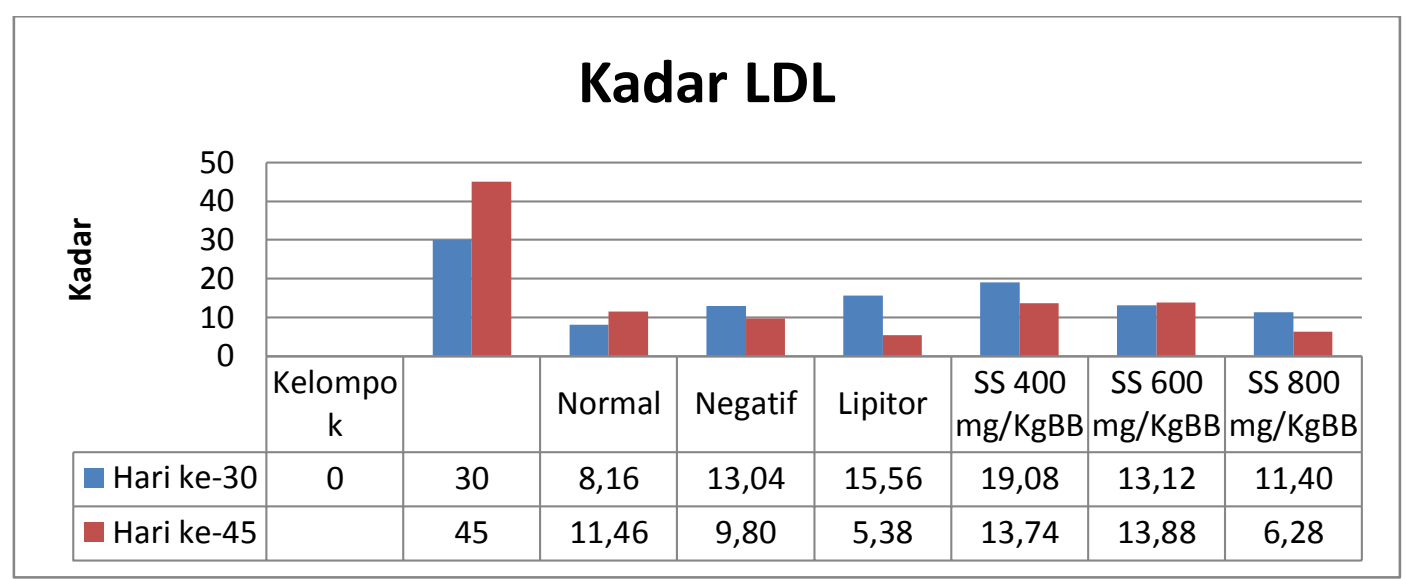

Gambar 4. Persen perubahan kadar LDL setelah pemberian sediaan uji

Hasil uji statistika ANOVA menunjukkan Nilai F hitung adalah 1,732 dengan probabilitas 0,166. Karena probabilitas $>0,05$ maka Ho diterima, berarti keenam perlakuan tidak berbeda bermakna. Uji t Test menunjukkan bahwa probabiltas $>0,025$ berarti semua perlakuan pada hewan uji relatif sama tidak berbeda satu dengan lainna. Probabilitas pada hewan uji yang diberikan lipitor $40 \mathrm{mg}$ sebesar 0,0055 < 0,025 berarti pada pemberian lipitor berbeda bermakna dengan dengan perlakuan lainnya.

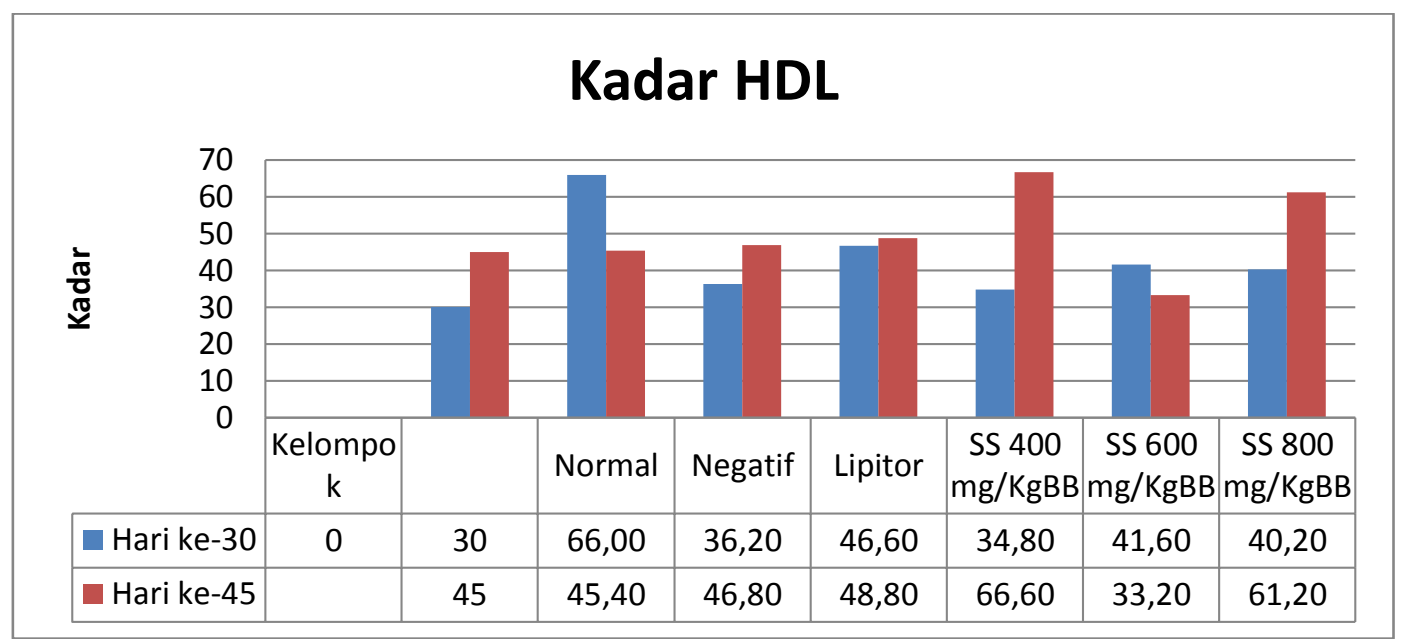

Gambar 5. Persen perubahan kadar HDL setelah pemberian sediaan uji

Berdasarkan gambar 5, kadar HDL pada pemberian ekstrak tumbuhan sarang semut menunjukkan peningkatan kadar HDL terutama pada dosis $400 \mathrm{mg} / \mathrm{KgBB}$ dan dosis $800 \mathrm{mg} / \mathrm{KgBB}$.Uji statistik ANOVA menunjukkan nilai $\mathrm{F}$ hitung adalah 5,926 dengan probabilitas 0,001. Karena probabilitas $<0,05$ maka Ho ditolak, berarti adanya perbedaan yang bermakna diantara perlakuan yang ada khususnya pada dosis $400 \mathrm{mg}$ dan $800 \mathrm{mg}$ terhadap perlakuan yang lainnya. Pada uji- 
t Test menunjukkan bahwa pada pemberian ekstrak tumbuhan sarang semut pada dosis $400 \mathrm{mg} / \mathrm{KgBB}$ memiliki probabilitas $0,0025<0,025$ dan pada pemberian ekstrak tumbuhan sarang semut dosis $800 \mathrm{mg} / \mathrm{kgBB}$ mempunyai probabilitas $0,0125<0,025$. Ini berarti kedua perlakuan tersebut menunjukkan adanya perbedaan hasil sebelum perlakuan dan sesudah perlakuan pemberian ekstrak tumbuhan sarang semut.

\section{Kesimpulan}

1. Ekstrak tumbuhan sarang semut Myrmecodia pendens Merr. \& Perry) memiliki potensi anhiperkolesterolemia untuk menurunkan kadar kolesterol total dan menaikkan kolesterol HDL pada tikus putih (Rattus norvegicus) jantan strain Wistar.

2. Ekstrak tumbuhan sarang semut Myrmecodia pendens Merr. \& Perry) memiliki potensi anhiperkolesterolemia (kolesterol total dan kolesterol HDL) pada tikus putih (Rattus norvegicus) jantan strain Wistar dosis $800 \mathrm{mg} / \mathrm{KgBB}$.

\section{Ucapan Terima Kasih}

Peneliti mengucapkan terima kasih kepada Direktorat Penelitian dan Pengabdian Kepada Masyarakat Direktorat Jendral Pendidikan Tinggi Kementerian Pendidikan dan Kebudayaan RI yang telah memberikan Hibah Penelitian Bagi Dosen Perguruan Tinggi Swasta Kopertis Wilayah VI melalui DIPA DIKTI Tahun Anggaran 2014 dan Pimpinan dan staf Akademi Farmasi Nasional Surakarta yang turut membantu terselesaikannya penelitan ini.

\section{Daftar Pustaka}

Anonim, 2006, Pharmaceutical Care untuk Pasien Penyakit Jantung Koroner,
Ditjen Bina Kefarmasian dan Alat Kesehatan, Departemen Kesehatan Ri, Jakarta.

Anonim, 2008, Epidemiologi PJK,

HIMAPID

http://himapid.blogspot.com/2

$\underline{008 / 10 / \text { penyakit- }}$

kardiovaskuler-pkv-

terutama.html (Senin, 27

Oktober 2008)

Anonim, 2010, Gambaran Penyakit Tidak Menular di Rumah Sakit di Indonesia tabun 2009 dan 2010, Pusat Data dan Informasi Kemenkes RI, Jakarta

Anonim, 2013, Penyakit Jantung Koroner, http://majalahkesehatan.com/p enyakit-jantung-koroner/ $\quad(5$ Desember 2013)

Azima F., 2004, Potensi Antihiperkolesterolemia Ekstrak Cassia Vere, IPB, Bogor, Jurnal Teknol dan Industri Pangan, Vol XV, No. 2 Tahun 2004

Lubis, E.N. 2007. Penyakit Jantung Koroner pada Anak dan Pencegahannya. Bagian Ilmu Kesehatan Anak Fakultas Kedokteran

Mayes PA. 2003, Sintesis, pengangkutan, dan ekskresi kolesterol. Didalam : Hartono A, alih bahasa; Bani AP, Tiara MN, editor. Biokimia Harper, 25th ed. Jakarta: EGC, 2003: 270-81.

Muspita Jelly M., 2011, Pengaruh Pemberian Infusa Tumbuhan Sarang Semut Terhadap Gambaran Histologi Pankreas pada Tikus Diabetes Terinduksi Aloksan, Majalah Kesehatan Pharma Medika, Vol 3 No. 1

Marks DB, Marks AD, Smith CM., 2000, Metabolisme Kolesterol dan Lipoprotein Darah, Didalam: Pendit BU, alih bahasa; Suyono J, Sadikin V, ManderaLI, editor. Biokimia Kedokteran Dasar: Sebuah Pendekatan Klinis, Penerbit Buku Kedokteran EGC, Jakarta

Malau MA, 2012, Epidemiologi Penyakit Jantung Koroner (PJK), 
repository.usu.ac.id/bitstream/ 1234 56789/31242/4/Chapter\%20II.p df (2 Mar 2012)

Purwanti T.T., 2011, Efek Propolis terhadap Kadar Kolesterol Total pada Tikus Model Lemak Tinggi, UKM Bandung, JKM, Vol 11 No. 1 Juli 2011, 17-22

Sumartono R. W., 1995, Pencegahan Penyakit Jantung Koroner di Indonesia, Puslit Penyakit Tidak Menular Badan Litbangkes Departemen Kesehatan RI, journal.litbang.depkes.go.id/index.ph p/MPK/article/viewFile/702/922
Subroto, M.A. \& Saputro, H. 2006. Gempur penyakit dengan sarang semut.Cetakan pertama, Penebar Swadaya Trubus no 438 edisi XXXVII (Mei 2006)

Tayeb R., 2012, Pengaruh Pemberian Infus Sarang Semut terhadap Kadar Asam Urat Darah pada Kelinci, Majalab Farmasi dan Farmakologi, Vol 16, No. 1

WHO, 2007, Prevention of Cardiovascular Disease Guidelines for assessment and management of cardiovascular risk. 